\title{
HOW I PUT THE HORSE BEFORE DESCARTES: AN AUTOBIOGRAPHICAL FRAGMENT
}

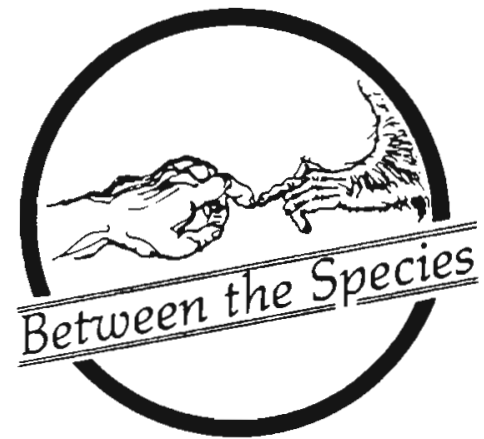

\author{
BERNARD ROLLIN \\ Colorado State University
}

Even as a child, I recall wondering why "humane" societies and animal "shelters" spent most of their time and effort "putting to sleep" healthy dogs and cats. The official "for their own good" response (what a friend of mine nastily labels "preventive death") didn't make a great deal of sense to me, and so I shrugged it off, figuring that this was yet another mystery which would be resolved when I grew up, along with other insoluble questions like where pencils came from and disappeared to, and how dirty jokes came into existence. Although I am now presumable "grown up," I have not yet received adequate answers to any of these questions. Perhaps, like particularly thorny questions of Talmudic pilpul, resolution awaits the coming of the (Jewish) Messiah.

In any case, although I retained an interest in animals and in questions surrounding their moral status, this interest was clearly demarcated from my academic concerns during my undergraduate and graduate years at CONY and Columbia. I emerged from Columbia, as did many other young acadenics, in a rather curious frame of mind. on the one had, I felt thoroughly overawed by my professors; totally ineffectual, obsequiously grateful that I had not been thrown out of philosophy, chronically guilty, committed to carrying the same ethos to whatever institution I went, determined to make it along accepted lines and hating myself for all of the above. On the other hand, part of me rebelled against allowing myself to be cast into such a mold and buying into the whole Eastern Ivy League treadmill. Responding to these suffocating pressures in a manner consistent with my heritage, I developed severe chronic asthma, which gave me the excuse to leave New York in search of breathable air for the body and a breathable atmosphere for the soul.

When I accepted a pasition at colorado State University in 1969, I carried this same ambivalence West. For my first five or six years in colorado, I worked primarily in areas which were consistent with Eastern academic values, though I was fortunate to be writing my dissertation under Professor Arthur Danto (probably the most brilliant and broad ranging mind I have ever known), who encouraged me to cut my own path. My interests at that time centered around philosophy of language, theory of meaning, and history of philosophy, primarily Hume and kant. (I had studied the latter philosophers as a Fulbright Fellow in 1964-65 at Edinburgh, under Professors G. E. Davie and W. H. Walsh.) By 1976, I had published Natural and Conventional Meaning: An Examination of the Distinction, a series of articles in a variety of areas, and in a masochistic scholarly frenzy edited, translated, and annotated The PortRoyal Gramar with a CSU colleague, Jacques Rieux. By 1976, I was on the verge of promotion to full professor. My only work in the animal area had been in 1969, when, following my childhood concerns, I wrote off to a dozen or so publishers suggesting that we undertake an anthology dealing with human obligations to other animals. When no one even nibbled at this suggestion, I laid it aside, figuring that the whole idea was just too deviant for the mainstream acadenic cormunity.

Had I been anywhere else but CSU, that may well have been the end of my attempt to deal with these issues in any formal way. But the situation at CSU was sufficiently unique that, happily, this did not occur.
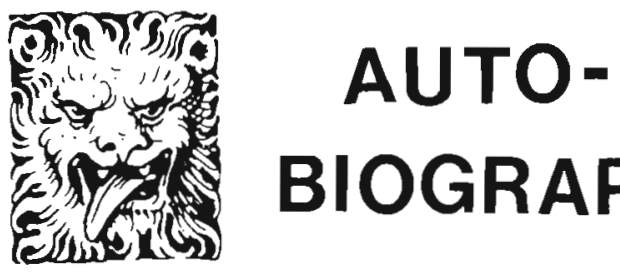

BIOGRAPHY 
First of all, the CSU philosophy department was probably the most congenial atmosphere an acadenic could ever hope for. The department of eighteen people had been created by Professor Willard O. Eddy during the expansionary 1960's. Eddy, a University of Chicago product, was determined to create a firstrate department while avoiding the pressures which pervaded most excellent institutions. In order to do so, he first of all hired young Ph.D.'s and almost Ph.D.'s only from institutions--Yale, Columbia, Chicago, Princeton, Michigan, Stanford, Edinburgh, Minnesota--when most other departments at CSU were hiring from the mid-West alone. Second, he hired for congeniality and collegiality as much as for intellect. Third, he urged his people to do their own thing, regardless of curcent philosophical fads. Fourth, he encouraged department members to devote at least part of their time to what is today called "applied philosophy," which he saw as a socratic function of primary importance in a land grant school, only lately became a university. The result was a truly unique department in which everyone attended everyone else's paper-readings, respected and read one another's work, engaged in regular dialogue, and virtually split their salaries equally. Out of this atmosphere came what has been described by administrators as a "world-class" philosophy department, a number of whose members enjoy international reputations in such diverse areas as environmental ethics, Zoroastrian studies, philosophy of psychology, and animal rights.

By 1976, I was feeling a great need to change my intellectual direction, having become somewhat restless with traditional acadenic concerns. My "applied" work in the department had been in human medical ethics, and in the early 1970's, I had successfully developed what I believe is one of the first undergraduate courses in ethical and philosophical issues in medicine ever done in the United States. In 1975, I was approached by Dr. Harold Breen, Professor of Pathology in the School of Veterinary Medicine, who asked if I were willing to undertake a similar project for veterinary students, something which had never before been done. After giving his suggestion a bit of thought, it occurred to me that the fundamental questions for veterinary ethics surely revolved around the moral status of animals. At the same time, my old interest in ethics and animals had been rekindled by my work in the theory of meaning and in the history of philosophy.
In eight years of teaching and writing in the history of philosophy, I had found virtually nothing addressing the grounds for excluding animals from the scope of moral concern. Philosophers had mostly neglected the issue in their writings on ethics. Furthermore, I found that most philosophers tended to demarcate humans from animals by virtue of the fact that humans possessed language. I saw no moral relevance in this claim and in my work on meaning had become convinced that there was, in fact, no difference in kind between human language and natural signs.

When approached by the veterinarian, I realized what a golden opportunity I was being offered. Here was a chance to develop my ethical ideas in the context of a group whose raison d'etre was the health and welfare of animals, yet who had absolutely no articulated awareness of the moral questions underlying their profession. Here, too, was a chance to weld theory and practice and to effect real change. (In my view, then as now, applied philosophy is merely wheelspinning if it does not result in practical differences.)

At the same time, getting the veterinary college to accept such a course, which might well subvert much of their accepted practice, was no easy task. Doubtless through the good offices of God, I chanced to catch one of the junior faculty members of the veterinary college attempting to do unnecessary major surgery on $\mathrm{my}$ own dog in order to provide an interesting case for the students. Under threat of grievous bodily harm, he confessed that he had lied to me, claiming that he had been trained to do anything at all to get the client "off his back." With this lucky incident as a lever, I was able to convince Dr. William Tietz, then Dean of the Veterinary School, to institute the course on an experimental basis. That he did, and immediately left to become president of Montana state University, leaving his successor, Dr. Robert Phemister, saddled with me and the course. Fortunately, Dr. Phemister is a man of deep moral concern, with a strong liberal education and a deep commitment to educating--not merely training--veterinarians. Under his aegis, the course went smoothly in one year from an experiment into a required part of the veterinary curxiculum.

As the first day of class approached, I was wracked with doubts. There was no precedent for such a course, no texts to fall back on, no previous syllabi. Furthermore, uni- 
versity folklore depicted veterinary students as very bright troglodytes; red-necks, cowboy shitkickers with no respect for pure science, let alone for philosophy. Fortunately, Dean Phemister had presciently suggested that I take as a co-teacher Dr. Harry Gorman, Assistant Dean, former chief veterinarian for the Aerospace Program, inventor of the artificial hip joint, and one of the great figures in American veterinary medicine. six hours of intellectual sparring with Harry convinced me that he was a superb dialectician, a morally concerned individual, and, most important, a figure authoritative enough to prevent riy being lynched by the students.

On the first day of class, I planned to approach the students in a straightforward way, challenging then to articulate their moral ideas, criticizing their education as rote memorization and Marine corps type spoon-feeding which, as one faculty nember cordially told me, was aimed at producing "not thinking men, but professional veterinarians." This I did at that initial meeting, but not before all my pent-up anxiety burst forth in what turned out to be a salubrious cleaning of the aix.

As I began to lecture, I noticed four cowboys in the back of the roam--hats on, chewing tobacco, boots perched on the desk in front of them, smirking at me and making sotto voce cracks among themselves. Something smapped in me, and I turned on them. "Look," I thundered, "I know you guys are taking nineteen required hours, that you have tons of work, and that the last thing you think you need is some goddarm hippie New York Jew pinko-commie philosopher bullshitting about right and wrong. But if you listen real good, you might learn something, because I'm a helluva lot brighter than you and know a lot more science than you do. And, in any case, if you don't wipe those smirks off your faces, I'm going to take you out in the hall and do it for you." This juvenile outburst was perfect-I had unwittingly approached them on familiar macho grounds and had gotten their attention.

Those students were extraordinary. By mid-year, they were convinced that the practice common in virtually every veterinary and medical school in the U.S. and canada of using the same dog over and over for surgery practice, scmetimes for as long as one year, was morally, scientifically, and clinically indefensible. In what was certainly a first in any veterinary school, the students en masse objected to the practice. Although Imuch of the faculty was hostile to the idea of students doing anything but ticking off multiple choices, many faculty members were not and, like Drs. Gorman and Phemister, had, on reflection, deep reservations about doing such a thing simply for economic expediency. As a result, csu became the first veterinary school to abolish multiple survival surgery on moral grounds, and set an example which most veterinary schools were to follow in the next half dozen years.

Shortly after the course was established, I began to receive invitations to lecture at other veterinary colleges and to help them institute programs in ethics until, by 1984, I had lectured at almost three-fourths of the veterinary schools in the U.S. and Canada. I also began to publish papers in veterinary journals, arguing for such courses as well as for veterinary concern for animal rights. Though I had been warned repeatedly that veterinary medicine was still very exploitative in its way of looking at animals, reflecting its agricultural roots, I have found veterinarians and veterinary schools very supportive of rly work. This did not surprise me--I have always operated on the assumption that the vast majority (probably 858) of the people who choose to become veterinarians---by no means a lucrative profession nor an easy life-do so because they care deeply about animals and seem them as possessed of intrinsic value, not merely instrumental or economic value. As I tell my veterinary audiences, the situation is easily characterized in Socratic terms: as a philosopher, I cannot teach-cannot force moral concern upon them-at most, I can help them remenber, recollect, and give systematic expression to that moxal concern which, in an intuitive way, brought them to the field in the first place, but which gets buried and forgotten through pressures of economics, practicality, habit, peer-pressure, and an educational system designed to produce a trained and predictable corps of "professionals."

I have, I believe, been very successful in this area; more and more schools have introduced these notions into their curricula; organized veterinary medicine has slowly become more concerned with animal welfare issues; many odious practices, like multiple surgery, have been abolished; veterinary educators and teachers have become far more sensitive to the issues. I am, of course, 
personally gratified by the frequent invitations I get to address local and state veterinary groups, as well as veterinary colleges, and overwhelmingly find enthusiasm rather than hostility for my ideas. There is, of course, much to be done, but I believe that veterinary medicine has basically become concerned. In 1983, to my deep amazement and gratitude, I was awarded the rare Veterinary Service Award by the Colorado Veterinary Medical Association for outstanding contributions to veterinary medicine.

At the same time as I got involved with the CSU veterinary college, another fateful occurrence which incalculably affected my work in animal welfare transpired. This was the appointment of Dx. David H. Neil as Director of Animal Care--laboratory animal veterinarian--at CSU. I first crashed into his office one afternoon shortly after his arrival to berate him about an animal use proposal of his. To my amazement, he listened; we argued, in fact, for nine hours, until he finally conceded that I was right and withdrew his proposal (perhaps as much out of bladder pressure as intellectual pressure). In any event, I found him to be an extraordinarily intelligent, sensitive, welleducated, philosophically sophisticated man, deeply concerned about animals, who had always felt that animal welfare issues cried out for rational, philosophical treatment. During his work with the Canadian Research Council, in fact, he had tried unsuccessfully to enlist the help of philosophers, none of whom at the time wished to sully themselves with empirical matters. He offered me the opportunity to work with him virtually on a daily basis, on matters ranging fram running a laboratory animal facility to educating researchers about animal rights, to writing meaningfully legislation to assure the welfare of laboratory animals, and I jumped at the chance.

For the past eight years, I have worked with David Neil and his people and have become very knowledgeable in all aspects of laboratory animal care and use; more knowledgeable, I am told by laboratory animal veterinarians, than many researchers who use animals. This knowledge and experience has given me a great deal of credibility with researchers and laboratory animal veterinarians and technicians, and I address groups of then with great regularity. Throughout my dealings with Neil, he has repeatedly hammered away at the point that everyone invol- ved with animal welfare must regularly ask themselves if the animals are any better off in virtue of their efforts, or if they are simply working in the area to feel virtuous, pure, rebellious, or noble. All too many people forget about the animals while supporting a principle. Anyone who thinks, for example, that working toward the use of analgesia for lab animals is a sell-out and that one ought to work only to abolish all animal experimentation, has clearly forgotten what it is like to hurt.

At the same time, along with David Neil, Dx. Gorman, and Robert Welbom, a prominent Denver attorney, I was engaged in drafting what became the so-called Schroeder Bill on laboratory animals, which subsequently became the Walgren and Dole Bills. The basic concept of the bill was to create legislation which covered the actual conduct of research, not just transportation, housing, etc., as does the Animal Welfare Act,. and which covered all animals used in research and teaching. (The Animal Welfare Act exempts from its coverage rats and mice, who constitute 708 of the animals used in research, and farm animals.) The bill mandated the abolition of multiple survival surgery and required control of pain not essential to the logic of an experiment by anaesthesia and analgesia. (Laboratory animal analgesia is almost never used in the U.S., especially on rodents, though, ironically, all analgesics are tested on rodents.) All of this was to be enforced by local review committees analogous to those which review research on human subjects. At least one member of the comittee was to be from the community, representing animal welfare interests. In 1982, I testified before Congress on behalf of the Walgren version of the bill. Ironically, although no version of the bill has yet been passed, and all versions were opposed by the National Institutes of Health, in the spring of 1984, NIH itself proposed guidelines for federally funded research institutions which essentially replicate most of the key features of the Schroeder bill.

By the time that I testified before Congress, it had become very clear that animal welfare issues were rapidly becoming a major social concern. Hundreds of bills had been introduced at state, federal, and local levels dealing with these issues. And in Europe and Canada, protests, laboratory seizures, and "trashings" were becoming common occurrences. The old, sentimental, "humane" 
ethic, characterized by primary concern for dogs and cats to the exclusion of less lovable animals, had been replaced by a new animal rights ethic, whose promulgators were better organized, better informed, and more activist. Starting in 1978, I was called upon with ever-increasing frequency to speak and consult for animal welfare groups in the U.S. and Canada. Of great mutual benefit was my work with Drs. Michael Fox and Andrew Rowan of the Institute for the Study of Animal Problems, and my regular consultations for Mr. Neil Jotham of the Canadian Federation of Humane societies. I am currently working with CFHS on a proposal to elevate the legal status of animals above that of property, and we have recently submitted a brief to this effect to the Canadian Law Reform Commission.

At the Congressional hearing on the Walgren Bill, it was clear that I and others had made some rational headway with the scientific community. The Anerican Veterinary Medical Association endorsed the Walgren Bill, and I personally carried the endorsement of the American Physiological Society, historically the traditional opponent of any external intrusion into the research process, and the endorsement of a variety of research institutions. Fatal opposition to the bill came primarily from the human medical research commuity, whose members are used to doing pretty much as they please and who have displayed no sensitivity whatever to this issue, being content to mouth irrelevant platitudes like "animal research yields human benefits," to list time-worn examples of these benefits, and to pose a false dichotomy between animal welfare and human welfare. (I once debated the head of the National Society for Medical Research, who proceeded to tell the astonished audience that $45 \mathrm{Nobel}$ Prize winners had used animals in their research, therefore, all researchers had the right to do what they wish to animals and that, in any case, nothing questionable is done to any animal in any medical or veterinary school in the U.S.)

In my speeches before medical and other researchers, I have tried to demonstrate the harmony between proper treatment of animals and the goals of good research, citing many examples of research rendered useless by a failure to control for stress variables and for the physiological effects of pain, fear, anxiety, etc. I also emphasize the moral abligations entailed by animal research done for human benefit and the moral onus upon researchers to maximize the welfare of the animals that they use. I have made these points repeatedly in published papers and in my 1981 book, Animal Rights and Human Morality (Prometheus Books), which was written to provide both animal welfare advocates and scientists with a rational and practicable point of departure for discussing the general

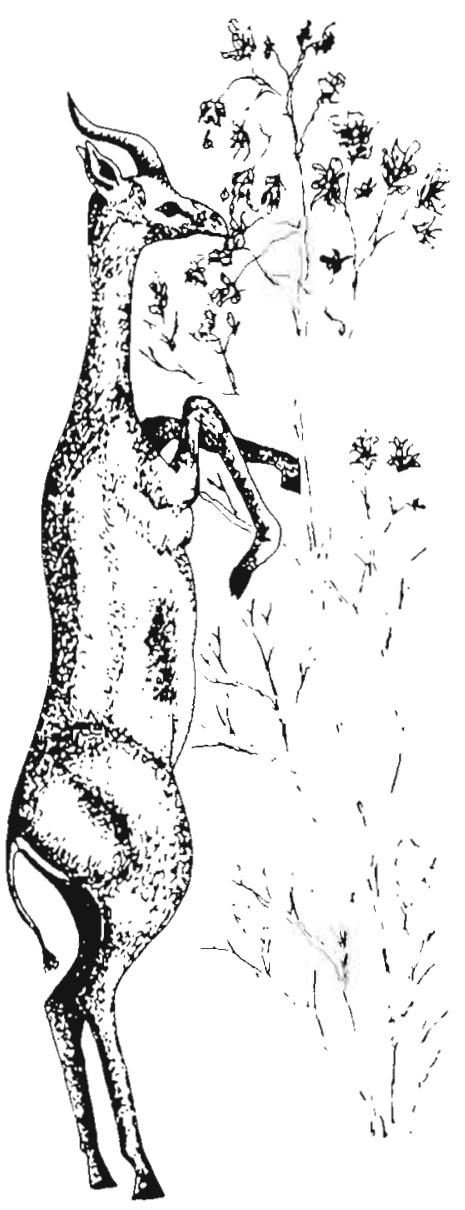

issue of animal rights and human moral obligations to animals, as well as many specific welfare issues. I hoped to provide common ground for both sides to engage in dialogue and to make things better for the animals. The book has sold well and has in general been well-reviewed by both sides in dozens of journals. (It was, in fact, named best academic book of the year in the general category by the American Association of University Libraries.) I say "in general," because it has also garnered some outrageous responses. I was called a "Nazi" and a "labtrasher" by a reviewer in the New England Journal of Medicine, which also refused to print my response to this scurrilous document. On the other side, I was called a 
"sell-out" for "accepting the reality of science" by a leading animal activist publication.

Truly, the animal welfare issue brings out the craziness which lies dormant in most of us, primarily, I am convinced, because animals are not a constituency and have no voice with which to press for meaningful reforms. As a result, both sides can get as extreme and self-indulgent as they wish. To often, scientists tend to deny that there is a problem, while "humaniacs" engage in kamikaze campaigns directed at activities they only dimly understand. Being in the middle, I have, predictably, often borne the brunt of this lunacy. After I gave a speech advocating reason in the movement at one humane organization, a senior officer of the organization became uncontrollably enraged and later told the group that they "didn't need reason or Jew logic" in the organization, only "emotion and Christian ethics." At a scientific meeting where I had been invited to give an hour-long, after-dinner speech a year in advance, the president of the society would not shake my hand and told me not to speak for longer than fifteen minutes "because no one will listen to you for any longer than that." I have been told more than once that it is fortunate that I an large (225 lbs.), strong ( I am a weightlifter and some time ago bench-pressed over 500 lbs.), and mean, and enjoy a welldeserved reputation for quick, nasty, and deadly comebacks.

Over the years, I have becone convinced on the basis of my own experience that the best hope for animals comes from education and legislation, where legislation primarily serves an educational function to present moral concern for animals "writ large." Most people, be they scientists, animal welfare advocates, or members of the public, are woefully ignorant of the conceptual, moral, and scientific aspects of issues pertaining to the place and treatment of animals in society. This is not surprising, since so few of these issues are ever formally exanined even in the best universities. The major thrust of my own activity, I suppose, has been to create acadenic respectability and academic housing for these questions as a vehicle for social change. In addition to the veterinary course, I team-teach a oneyear freshman honors biology course at csU with Dr. Murray Nabors, where we are caunitted to showing students that moral and philo- sophical questions, including animal rights questions, are inseparably part of the very essence of science and ought to be learned by nascent scientists along with more traditional empirical material. I also teach a course for animal science students on ethical issues in intensive animal agriculture and have found these students, contrary to stereotypes, to be among the brightest, most sensitive, and most morally concerned students I have ever encountered. I an currently at work coordinating a course for graduate students who use animals, dealing not only with animal issues in animal research but also with nuts and bolts techniques, such as handling, analgesia, and euthanesia, which, if not employed properly, can engender untold amounts of suffering for animals.

A great deal of ny time is spent in dialogue with faculty who use animals, learning their concerns and problems and attempting to sensitize them to moral questions by giving such provocative lectures as "The Philosophier and the Cow's Rectum," which was very well-attended. I am constantly in search of scientists and veterinarians who, as it were, take naturally to these issues, for it is they who can best build awareness of these questions into the fabric of scientific activity and education. I have been fortunate to find a fair number of such people all across the country, but I seen especially blessed at CSU. My Colleagues in the sciences have been wanderfully receptive to my critiques of current practice and have, in fact, appointed me jointly in the Department of Physiology and Biophysics. one of my best students, Dx. M. L. Kesel, a true Renaissance person, is now employed as a laboratory animal veterinarian with David Neil and has demonstrated a unique ability to integrate science and ethics. She, in turn, is now involved in teaching others, and so it grows.

My animal-related activities have grown beyond anything I foresaw eight years ago. To date, I have done in excess of 300 lectures all over the U.S.. Canada, and Europe, from Poland to Britain, to groups ranging from attorneys to trauma researchers to psychologists and zoologists, and average at least 25 trips each year. I have engaged in debates, given keynote speeches, presented endowed lectures, delivered graduation addresses, testified before legislatures, held seminars for govermment agencies, appeared on television and radio and in documentaries, 
been featured in magazines, and helped develop courses of study. I have seen people at their stupidest and most intransigent, yet I have also, on many occasions, seen the efficacy of reason and witnessed the triumph of decency over self-interest. In the midst of all of this tumult, I have been fortunate, indeed, to enjoy the security of a stable home life and have benefitted fran living with a wife and son (born in 1979), both of whom are considerably brighter than I am. (By the time my wife, a mathematician, has finished going over my papers and speeches and rubbed my nose in every conceptual flaw, I am morally certain all my bases are covered and am prepared to face anyone.) My little boy has attended my speeches and lectures so often that he has only to hear the word "ethical" and he falls instantly asleep. When I gave the $c$. $W$. Hume Memorial Lecture at kings college, London, in fact, he sat erect in the first row, much to the amazement of the audience, apparentiy absorbed in the lecture, and slept quietly from the first sentence on, to be awakened only by the applause, in which he enthusiastically took part.

For the immodiate future, I anticipate working primarily on the treatment of animals in science, not because there aren't other areas of pressing concern, but because it is the area I know best. Then, too, despite frequent lapses, scientists are professionally comitted to abiding by the rule of reason and are, thus, amenable to rational and scientific persuasion. Where profits and bottom line are, as it were, the bottam line, as in animal agriculture or in horse-racing, rational argument is obviously not the most effective force for change.

In addition to the all-important moral dimension, it seems clear to me that the issue of animal use in science teaches us much about the nature of science. For if, as scientists frequently say, contemporary biomedicine is essentially dependent on invasive use of animals, surely they cannot also claim as part of the ideology of science that science is value-free, since every such invasive use of animals presupposes the moral judgment that the benefit gained by science is of greater value than or trumps the animal pain or suffering. Also, the scientist's ability to ignore the common sense demands of morality when dealing with laboratory animals is itself a fascinating phenomenon, based in part upon a widespread notion integral to the ideology of science that one can make no judgments about animal feelings and awareness and that imputation of consciousness to animals is anthropanorphic and scientifically meaningless. This in turn leads to bizarre Cartesian claims that animals don't really feel pain; they only "vocalize" or "show aversive behavior." My most recent work is designed to confute the orthodox view that claims about animal minds are meaningless and to show that it was basically an indefensible historical accident, inconsistent with fundamental biological prenises, but pragmatically expedient, which led to a denial of mentation to animals. In this way, I hope not only to change the scientific gestalt on animal consciousness but to shed light on the less than rational manner in which scientific change takes place.

As the concept of local and public review of animal research gains credence, people will become increasingly aware, as, indeed, they have in the human research area, that moral deliberations are not bull-sessions and do not take place in a vacurm. This, I hope, will in turn ensure that the tissue of questions surrounding these moral issues about animals will become the object of serious study and research and, correlatively, receives academic respectability and a place for study in institutions of higher learning. only in this way can such issues become a permanent and legitimate area of emphasis in a democratic society.

continued from page 31

1. Rene Dubos, A God Within (New York: Charles Scribnex's Sons, 1972), pp. 45.

2. Andre Leroi-Gourhan, Treasures of Prehistoric Art (New York: Harry N. Abrams, Inc.., 1967), p. 121.

3. Ibid., p. 118.

4. Wing Tsit-Chan, The Way of Lao-Tzu (Indianapolis: Bobbs-Merrill Co., 1963), p. 6.

5. Ibid., p. 144 .

6. Ibid., p. 144.

7. Ibid.. p. 176.

8. Ioid.. p. 176.

9. Ibid., p. 195. 